https://doi.org/10.18778/7525-969-8.27

\author{
Ewa Bujwid-Kurek
}

\title{
Wybrane zagadnienia ustrojowe współczesnej Republiki Serbii
}

Za główny cel badawczy przyjęto omówienie systemu naczelnych organów państwowych Republiki Serbii w świetle zapisu konstytucji Serbii z 2006 r. Stąd też analizie poddane zostaną: Zgromadzenie Narodowe (Narodna Skupština) Republiki Serbii, instytucja prezydenta, rząd, Sąd Konstytucyjny, którego rola w omawianym systemie jest szczególna. Także warta uwagi wydaje się instytucja Obrońcy Obywatela (Ombudsman), choć nie będąca w ścisłym tego słowa znaczeniu elementem składowym aparatu państwowego, to jednak mająca niebagatelne znaczenie jako przykład instytucji stojącej na straży praworządności, zwłaszcza we współczesnej Republice Serbii. Analiza ta ma posłużyć ustaleniu, czy ustrojodawca serbski w wystarczającym stopniu zadbał o to, by konstytucyjny zapis dotyczący wyżej wymienionych organów państwa był adekwatny do wymogów demokratycznego ustroju politycznego.

\section{Zgromadzenie Narodowe}

Zgromadzenie Narodowe Republiki Serbii, podobnie jak organy legislacyjne, jest organem władzy publicznej wyodrębnionym pod względem organizacyjno-kompetencyjnym, uprawnionym do podejmowania w imieniu państwa czynności prawnych ze skutkiem wiążącym dla innych podmiotów. Ustawodawca w Republice Serbii powierzył Zgromadzeniu Narodowemu, na zasadzie wyłączności, określone kompetencje władcze, czyli możliwość oddziaływania na zachowania innych podmiotów. Zgromadzenie Narodowe jest organem państwa wykonującym swe uprawnienia bezpośrednio, zastępując obywatela, będącego w serbskim systemie politycznym podmiotem suwerena, a nie działającym w czyimkolwiek imieniu. W związku z powyższym Zgromadzenie Narodowe w Republice Serbii jest najwyższym jednoizbowym ciałem legislacyjnym. Owa jednoizbowość w niczym nie przeszkadza, bynajmniej nie godzi w ustaloną ideę systemu demokratycznego. 
W skład Zgromadzenia Narodowego wchodzi 250 deputowanych, którzy wybierani są w wyborach bezpośrednich, w głosowaniu tajnym (art. 100). Zgodnie z cytowanym artykułem stanowi się nadto, że w Zgromadzeniu Narodowym gwarantuje się równouprawnienie płci oraz przedstawicieli mniejszości narodowych, co czyni się zgodnie z prawem. Wybory do Zgromadzenia Narodowego rozpisuje prezydent republiki 90 dni przed upływem poprzedniej kadencji, tak by posiedzenie odbyło się najpóźniej 30 dni od dnia ogłoszenia ostatecznych wyników wyborów i tak, by mogły one być zakończone w przeciagu $60 \mathrm{dni}$ od ich rozpoczęcia. Zgodnie z konstytucyjnie przyjętym zwyczajem pierwsze posiedzenie Zgromadzenia Narodowego otwiera przewodniczacy Zgromadzenia Narodowego ${ }^{1}$. Zgromadzenie Narodowe konstytuuje się poprzez zatwierdzenie mandatów przez wymagane gremium $2 / 3$ deputowanych. W kwestii mandatu deputowanego konstytucjonalista serbski dopuszcza złożenie skargi konstytucyjnej do Sądu Konstytucyjnego, który jest zobowiązany orzec w tej kwestii w ciagu 72 dni. $Z$ chwilą zatwierdzenia mandatu przez $2 / 3$ deputowanych wygasa mandat poprzedniej kadencji Zgromadzenia Narodowego (art. 101).

W rozdziale V, zatytułowanym Organizacja władzy, w punkcie 1, w art. 98 konstytucji stanowi się, że „Zgromadzenie Narodowe jest najwyższym ciałem przedstawicielskim i organem władzy ustawodawczej i konstytucyjnej Republiki Serbii”. Co do kompetencji ustawa zasadnicza stanowi w kolejnym art. 99 i wymienia je następujacco: uchwalanie i zmiana konstytucji, podejmowanie decyzji w sprawie zmiany granic Republiki Serbii, rozpisywanie referendum na poziomie republiki, zatwierdzanie umów międzynarodowych (jeśli ustawa przewiduje takie czynności), decyduje o wojnie i pokoju oraz ogłasza stan wojenny i stan nadzwyczajny, nadzoruje prace służby bezpieczeństwa, uchwala ustawę o innych ogólnych aktach prawnych ${ }^{2}$ w kwestii zakresu kompetencji Serbii, wydaje wstępną zgodę na statut autonomicznych pokrain ${ }^{3}$, akceptuje strategie obrony państwa, zatwierdza plan rozwoju i zagospodarowania przestrzennego, zatwierdza budżet i bilans Republiki Serbii wedle przedłożonych wcześniej propozycji rządu, decyduje o amnestii za przestępstwa karne. Nadto w ramach swoich kompetencji kreacyjnych Zgromadzenie Narodowe wybiera rząd, nadzoruje jego pracę i decyduje o wygaśnięciu mandatu rządu i jego poszczególnych ministrów, wybiera sędziów Sądu Konstytucyjnego, wybiera przewodniczącego Najwyższego Sądu Apelacyjnego, przewodniczącego sędziów, prokuratora generalnego Republiki, prokuratorów, sędziów i zastępców prokuratorów zgodnie z konstytucja, wybiera prezesa Narodowego Banku Serbii i nadzoruje jego pracę,

${ }^{1}$ Odpowiednik polskiego marszałka Sejmu.

${ }^{2}$ Ogólny akt prawny, nazwa ta nie ma tożsamego odpowiednika w nauce polskiego prawa konstytucyjnego. Ich istotę można porównać z aktami prawnymi nie będącymi konstytucją (przy czym głównie chodzi o ustawy).

${ }^{3}$ Pokraina synonimicznie oznacza prowincję, okręg autonomiczny. 
wybiera Obrońcę Obywatela i nadzoruje jego pracę, decyduje o pełnieniu innych funkcji przewidzianych w ustawie.

Jeśli chodzi o status ustrojowy Zgromadzenia Narodowego, to w art. 102 zapisano, że od momentu zatwierdzenia mandatu deputowanego jego kadencja trwa cztery lata. Natomiast decyzje o ewentualnym przerwaniu kadencji scedowane zostały na Zgromadzenie Narodowe. Mandat deputowanego ma charakter wolny, pod warunkiem, że działa on zgodnie z prawem, i jest nieodwołalny ${ }^{4}$. Deputowanego obowiązuje zasada incompotabilitas, polegająca w tym przypadku na bezwzględnym niełączeniu sprawowanej funkcji z pełnieniem analogicznej funkcji deputowanego w autonomicznych pokrainach, pełnieniu funkcji w naczelnych organach władzy, w sądownictwie, jak też pełnienie funkcji, które mogłyby rodzić „wzniecanie konfliktów interesów”. Zarówno sam wybór, wygaśnięcie mandatu, jak też status deputowanego określa ustawa. Zgodnie $\mathrm{z}$ art. 103 konstytucji deputowanemu przysługuje immunitet, którego idea fixe tkwi w klasycznym prawnokonstytucyjnym jego rozumieniu. Otóż na czele Zgromadzenia Narodowego stoja przewodniczacy oraz jego zastępca(y). Artykuł 104 stanowi, że „Zgromadzenie Narodowe większościa głosów wszystkich deputowanych wybiera przewodniczącego i jednego lub więcej zastępców przewodniczącego Zgromadzenia Narodowego". Większością głosów, generalnie rzecz biorąc, Zgromadzenie Narodowe decyduje we wszystkich wcześniej wymienionych kwestiach. Także podejmuje decyzje w sprawie terytorium autonomicznych pokrain i jednostek samorządu terytorialnego oraz w kwestiach związanych z korzystaniem z indywidualnych i kolektywnych praw zarezerwowanych dla mniejszości narodowych.

Zgromadzenie Narodowe obraduje na dwóch sesjach zwyczajnych, z których pierwsza rozpoczyna się w pierwszym dniu roboczym marca, a druga w pierwszym dniu roboczym października. Ustalono, że sesja zwyczajna nie może trwać dłużej niż 90 dni. Przewidziano także możliwość zwołania sesji nadzwyczajnej, co może być wynikiem wniosku przegłosowanego przez co najmniej 1/3 deputowanych lub też honorowany jest $\mathrm{w}$ tym względzie wniosek rządu z wcześniej przedstawionym porządkiem obrad. Zgromadzenie Narodowe zbiera się także po ogłoszeniu wojny lub stanu nadzwyczajnego (art. 106). Zgromadzenie Narodowe per analogia, jak niemal wszystkie typowe ciała legislacyjne, posiada prawo inicjatywy ustawodawczej w zakresie aktów prawnych oraz ogólnych aktów prawnych, co należy rozumieć tak, że każdemu deputowanemu przysługuje prawo inicjatywy ustawodawczej ${ }^{5}$. Zgromadzenie Narodowe może być rozwiązane na uzasadniony wniosek rządu przez prezydenta Republiki Serbii

${ }^{4}$ W tym miejscu należy wyjaśnić, że chodzi tu o nieodwołalność, która leży w kompetencji partii politycznej, z której deputowany się wywodzi.

${ }_{5}$ Prawo inicjatywy ustawodawczej przysługuje także rządowi, parlamentom autonomicznych pokrain lub też minimum 30 tys. wyborcom (art. 196). 
(art. 109). Należy zauważyć, że w tym względzie przewiduje się takie sytuacje rozwiązania Zgromadzenia Narodowego w Serbii, jak przykładowo: może ono zostać rozwiązane, jeśli w okresie 90 dni od dnia ukonstytuowania się nie zostanie wybrany rząd. Konstytucja (art. 109) nie dopuszcza natomiast możliwości rozwiązania Zgromadzenia Narodowego podczas stanu wojny lub stanu nadzwyczajnego. Konstytucjonalista serbski zdecydował w zapisie konstytucji Serbii z 2006 r., że w kwestii Zgromadzenia Narodowego stanowi ustawa (art. 110).

\section{Prezydent Republiki Serbii}

Prezydent państwa, stanowiąc element władzy wykonawczej w każdym niemal systemie politycznym, bez względu na konstytucyjnie określoną formę rządów, należy do niezwykle istotnych części składowych aparatu państwowego. Czymś zupełnie oczywistym jest, że najbardziej znacząca pozycję przybiera urząd prezydenta w państwach, w których realizowana jest forma rządów prezydenckich (np. USA) bądź semiprezydenckich (np. Francja). W tych systemach bez wątpienia kompetencje głowy państwa są największe i relatywnie najszersze - w porównaniu z pozostałymi elementami składowymi zarezerwowanymi dla aparatu państwowego, zwłaszcza władzy ustawodawczej, choć nie są one wyłączne. Jednak mylne byłoby ograniczenie się tylko i wyłącznie do sygnalizowanych form rządów. Także i w rozwiązaniach ustrojowych, gdzie przyjęto formę parlamentarno-gabinetową (większość państw pojugosłowiańskich, w tym także interesująca nas Republika Serbii) pojawia się urząd prezydenta. Stąd też nie bez znaczenia jest, kto nominalnie ten urząd sprawuje. Chodzi tu nie tylko o cechy osobowe piastującego tę funkcję, pogłębiona refleksja politologiczna wręcz zobowiązuje brać także pod uwagę proweniencję ideowo-polityczną prezydenta oraz stopień korzystania z uprawnień powierzonych mu przez ustrojodawcę. Istotny jest też więc rozdział kompetencyjny między egzekutywą a legislatywa. Można także ustalać, czy w konkretnym branym pod uwagę systemie ma się do czynienia z tradycja prezydentury i ją akceptującym odbiorem społecznym (przypadek Serbii).

We współczesnej Republice Serbii prezydent wybierany jest w wyborach powszechnych i bezpośrednich (art. 114). Wybory na ten urząd rozpisuje Zgromadzenie Narodowe 90 dni przed upływem mandatu prezydenta republiki, tak by wybory zostały zakończone w przewidzianych 60 dniach, zgodnie z ustawą. Prezydent obejmując urząd jest zobowiązany do ślubowania, które brzmi: „Ślu-

${ }^{6}$ Więcej na ten temat patrz: E. Bujwid-Kurek, Fenomen prezydentury $w$ „młodych” państwach batkańskich, [w:] Myśl i polityka. Księga pamiątkowa dedykowana Profesorowi Jackowi Marii Majchrowskiemu, t. 2, red. B. Szlachta, Kraków 2011, s. 279. 
buję, że wszystkie swoje siły poświęcę ochronie suwerenności i nienaruszalności terytorium Republiki Serbii, włączając w to Kosowo i Metohiję jako jej część składową ${ }^{7}$, jak i realizowanie praw i wolności człowieka i mniejszości, poszanowania i przestrzegania Konstytucji i ustaw, ochrony pokoju i dobrobytu wszystkich obywateli Republiki Serbii, świadomie i odpowiedzialnie wypełniać wszystkie swoje powinności" (art. 114). Konstytucja przewiduje dla głowy państwa rolę „moderatora” (arbitra) (art. 111), którego zobowiązuje się do wykazania szczególnej dbałości w kwestii równoważenia się władz (legislatywy i egzekutywy), przy jednoczesnym oddzieleniu władzy sądowniczej. Niektóre obowiązki prezydent dzieli z rządem, jednak jego udział w tym podziale jest nieporównywalnie mniejszy. Ma się tu na względzie przede wszystkim uprawnienia, które zwykle zarezerwowane są dla głowy państwa, mianowicie ogłoszenie stanu nadzwyczajnego i podejmowanie środków, które pozwalają na odstapienie od praw człowieka i mniejszości podczas zaistnienia stanu nadrzędnej konieczności. Kompetencje w kwestii ogłoszenia stanu nadzwyczajnego zostały rozdzielone na tzw. triumwirat władzy, tzn. na prezydenta, premiera oraz przewodniczącego parlamentu, wspólnie podejmujących decyzję w tej kwestii. Natomiast środki odstapienia od praw człowieka i mniejszości zarządza rząd, a podpisuje prezydent. Prezydent Republiki Serbii upoważniony jest do rozwiązywania parlamentu przed upływem kadencji.

Wnikliwa analiza stanowienia $\mathrm{w}$ kwestii uprawnień głowy państwa w Republice Serbii jednoznacznie utwierdza w przeświadczeniu, że są one znacznie ograniczone, w zdecydowanej większości realizowane przy współudziale z rządem. Zatem można wnioskować, że konstytucyjnie przewidziany, mający się realizować zracjonalizowany parlamentaryzm, w tym przypadku o wiele bardziej uprzywilejowuje rząd. W kompetencjach prezydenta - zgodnie z art. 112 - znajduja się następujące uprawnienia: reprezentowanie Republiki Serbii w kraju i za granica, przedkładanie Zgromadzeniu Narodowemu kandydata na premiera, proponowanie Zgromadzeniu Narodowemu powołania osoby do sprawowania określonych funkcji, co winien czynić zgodnie z zapisem konstytucji i stosownymi po temu ustawami. Nadto prezydent powołuje i odwołuje ambasadorów Republiki Serbii korzystając z propozycji rządu, przyjmuje akredytacje i listy uwierzytelniające zagranicznych dyplomatów, dysponuje prawem łaski i przydziela odznaczenia, pełni też inne funkcje przewidziane w konstytucji. Nadto prezydent zgodnie z ustawa jest przywódcą sił zbrojnych, powołuje i mianuje oficerów sił zbrojnych Serbii. Do prezydenta należy także

${ }^{7} \mathrm{~W}$ tym miejscu pojawia się watpliwość, dotycząca ogłoszenia aktu niepodległości przez Kosowo, co nastapiło 17 lutego 2008 r., i jej prawomocnej uznawalności przez większość państw. Jednakże ta bardzo ciekawa i jakże kontrowersyjna kwestia nie pozostaje w centrum zainteresowania niniejszych rozważań, stąd też pogłębiona refleksja zostanie pominięta. Zainteresowanych odsyłam do swojego artykułu Zasady ustrojowe $w$ zapisie Konstytucji Republiki Serbii z 10 listopada 2006 roku, „Atheneum” 2012, nr 32. 
decyzja o skróceniu kadencji parlamentu i ogłoszeniu przedterminowych wyborów parlamentarnych ${ }^{8}$. Jak wynika z zapisu art. 115 cytowanej konstytucji, prezydent nie może piastować żadnego innego urzędu, ani też pełnić innej funkcji związanej z wyuczonym zawodem z wyjątkiem tych, które nieodzownie łącza się ze sprawowanym urzędem. Zasada incompatibilitas oznacza przede wszystkim to, że piastujący urząd głowy państwa nie może wchodzić w skład żadnego innego organu państwowego. Osoba wybrana do pełnienia tego stanowiska jest zobowiązana do rezygnacji ze wszystkich innych piastowanych przez siebie urzędów oraz do złożenia ewentualnie sprawowanego mandatu deputowanego. Osoba piastujacca urząd prezydenta Republiki Serbii nie powinna być powołana na żaden inny urząd, ani też nawet kandydować w wyborach, chociaż zasada, o której mowa, wcale nie oznacza pozbawienia biernego i czynnego prawa wyborczego. Pamiętać jednak należy, że zasada incompotabilitas, szczególnie w przypadku prezydenta, stanowi konieczną konsekwencję zasady podziału władzy, która to zasadę serbski ustawodawca jak najbardziej honoruje w najnowszych rozwiązaniach ustrojowych państwa. Za główny cel w tym względzie przyjęto stworzenie zabezpieczeń przed nadmierną koncentracją uprawnień w ręku jednostki. Jednym $\mathrm{z}$ elementów zasady podziału władzy w aspekcie personalnym jest przecież wymóg mówiący o tym, że w skład różnych organów państwowych nie powinny wchodzić te same osoby. Nadto należy podkreślić, że wprowadzenie wobec prezydenta Republiki Serbii zasady incompatibilitas ma na celu ochronę autorytetu sprawowanego przez niego urzędu, co w przypadku każdego niemal ustroju politycznego wydaje się niepozbawione znaczenia politycznego. Traktując sumarycznie konstytucyjne uprawnienia dane prezydentowi można zatem stwierdzić, że wyraźnie świadczą one o tym, że mamy tu do czynienia z przewidywaną konstytucyjnie relatywnie słabą prezydenturą. Prezydent Republiki Serbii symbolizuje jedność i niepodległość państwa ${ }^{9}$, co wynika expressis verbis z cytowanego wcześniej tekstu ślubowania.

8 Ówczesny prezydent Serbii Boris Tadić skorzystał z przysługującego mu prawa przedterminowego rozwiązania parlamentu, co uczynił 13 marca 2008 r. Wybory odbyły się w dniu 11 maja 2008 r. Było to spowodowane zaistniałym kryzysem politycznym w związku z ogłoszeniem deklaracji niepodległości przez Kosowo 17 lutego 2008 r. Warto pamiętać, że była to tylko jednoroczna kadencja parlamentu. Poprzednie wybory odbyły się w 2007 r. Po oderwaniu się Kosowa nastapił rozłam wśród partii parlamentarnych politycznych, takich jak opozycyjna Serbska Partia Radykalna (SRS), która opowiadała się za wstrzymaniem negocjacji z Unią Europejska, po tym jak większość państw UE poparła samodzielność Kosowa; Demokratyczna Partia Serbii Voijslava Koštunicy - akceptująca niepodległe Kosowo; Konserwatywno-Liberalna G17 Plus - przeciwna łączeniu akcesji do UE ze sprawą Kosowa; proprezydencka Partia Demokratyczna (DS) - popierająca opinie prezydenta Tadicia w sprawie Kosowa i UE.

${ }_{9}$ Prezydentem Republiki Serbii był do czerwca 2012 r. B. Tadić, jego następcą został Tomislav Nikolić. 


\section{Rząd}

W dualizmie egzekutywy, obok prezydenta mamy do czynienia z rządem jako drugim równolegle sprawującym władzę wykonawczą organem. W skład rządu wchodzi szef rządu (premier), jeden lub więcej wicepremierów i ministrowie (art. 125). Rząd (Rada Ministrów) w Republice Serbii, działając na podstawie aktów prawnych uchwalanych przez Zgromadzenie Narodowe, zatwierdza i realizuje zadania dotyczące zarówno bieżącej polityki wewnętrznej, jak i zagranicznej państwa, wydaje rozporządzenia i inne przepisy wykonawcze co do uchwalonych ustaw, przedkłada Zgromadzeniu Narodowemu projekty ustaw i innych aktów prawnych oraz wydaje opinie o projektach aktów prawnych zgłoszonych przez inne uprawnione podmioty. Nadto określa zadania organów administracji rządowej, koordynuje i nadzoruje ich prace.

Kadencja rządu jest równa kadencji Zgromadzenia Narodowego, przez który rząd został zatwierdzony (art. 128). Natomiast art. 127 konstytucji stanowi w kwestii procedury powoływania rządu. Kandydata na Prezesa Rady Ministrów (premiera) przedkłada Zgromadzeniu Narodowemu prezydent. Natomiast kandydat na premiera przedkłada Zgromadzeniu Narodowemu proponowany skład rządu i jego program. Należy zauważyć, że do powołania rządu konieczna jest bezwzględna większość głosów ${ }^{10}$. Rząd ponosi odpowiedzialność polityczną przed Zgromadzeniem Narodowym za wykonywanie ustaw oraz ogólnych aktów prawnych, jak też za pracę organów administracji państwowej (art. 124). W tym przypadku przewidziana jest odpowiedzialność polityczna ponoszona przez cały rząd za podejmowane przez niego decyzje, jak i odpowiedzialność indywidualna każdego z osobna ministra. Jeżeli sposób realizacji polityki przez rząd nie jest zgodny z wolą większości Zgromadzenia Narodowego, wówczas istnieje uzasadniona podstawa do pociagnięcia rządu do odpowiedzialności.

Ustawodawca serbski w art. 129 konstytucji przewidział, że minimum 50 deputowanych może wnieść interpelacje $\mathrm{w}$ związku z działalnością całego rządu lub któregoś z ministrów. W takiej sytuacji to właśnie na rządzie ciąży obowiązek udzielenia odpowiedzi na wniesioną interpelację w ściśle określonym czasie, który konstytucyjnie rzecz biorąc wynosi maksymalnie do 30 dni. Zapis ten świadczy o tym, że konstytucja Serbii przyznaje deputowanym tradycyjne uprawnienia kontrolne przysługujace członkom parlamentu w postaci prawa do składania interpelacji. Warto przypomnieć, że interpelacje składa się

${ }^{10}$ Od lipca 2008 do lipca 2012 r. władzę w Serbii sprawował gabinet, na którego czele stał Mirko Cvetković, stworzony przez koalicję partii z listy wyborczej „Na rzecz Europejskiej Serbii” skupionej wokół Partii Demokratycznej, bloku Socjalistycznej Partii Serbii (SPS) - Zjednoczonej Partii Emerytów Serbii (PUPS) - Niepodzielnej Serbii (JS) oraz partii mniejszości narodowych. Informacje za: http://www.msz.gov.pl (dostęp 2 VIII 2011). Od lipca 2012 r. na czele nowego rządu koalicyjnego stoi Ivica Dačić. 
w sprawach o zasadniczym charakterze i generalnie rzecz biorąc odnoszą się one do kwestii związanych z polityką państwa. Wniosek o wotum nieufności w sprawie odwołania rządu konstytucyjnie ujmując może zgłosić minimum 60 deputowanych (art. 130). W przypadku, gdy Zgromadzenie Narodowe zgłosi wotum nieufności wobec rządu, prezydent Republiki Serbii jest zobligowany do wszczęcia procedury w sprawie wyboru nowego rządu. Jeśli Zgromadzenie Narodowe nie zdecyduje o wyborze nowego rządu w przeciagu 30 dni od zgłoszenia wotum nieufności, to wówczas prezydent ma obowiązek powziać decyzję o rozwiązaniu Zgromadzenia Narodowego i rozpisaniu nowych wyborów parlamentarnych. Jeśli natomiast Zgromadzenie Narodowe zgłosi wotum nieufności tylko wobec któregoś z ministrów, wówczas szef rządu (premier) powinien skierować postępowanie w sprawie wyboru nowego ministra, co czyni zgodnie z prawem. W przypadku, gdyby Zgromadzenie Narodowe nie wystapiło z wnioskiem o wotum zaufania dla rządu, wówczas zarówno rządowi, jak i stojącemu na jego czele premierowi wygasa mandat. $\mathrm{W}$ takiej sytuacji prezydent ma obowiązek wszcząc procedurę w kwestii wyboru nowego rządu. W razie gdyby Zgromadzenie Narodowe nie wybrało nowego rządu w okresie 30 dni od dnia nieprzegłosowania wotum zaufania, prezydent ma konstytucyjny obowiązek rozwiąać Zgromadzenie Narodowe i rozpisać nowe wybory parlamentarne (art. 131). Także i wtedy, gdy Zgromadzenie Narodowe Republiki Serbii występuje z wnioskiem w sprawie dymisji szefa rządu, prezydent ma obowiązek wszczęcia procedury w kwestii wyboru nowego rządu. W sytuacji gdyby Zgromadzenie Narodowe nie zdołało wybrać rządu w ciagu 30 dni od dnia wnioskowania o dymisję szefa rządu, wtedy do powinności prezydenta należy rozwiązanie Zgromadzenia Narodowego i rozpisanie wyborów, co dzieje się zgodnie ze stanowieniem art. 132 konstytucji Serbii.

Gdyby natomiast chodziło o podanie się do dymisji któregoś z ministrów, to wówczas przewidziana jest następująca procedura: minister zgłasza dymisję szefowi rządu, który następnie przedstawia ten konkretny przypadek przewodniczącemu Zgromadzenia Narodowego, co w dalszej kolejności na pierwszym posiedzeniu sesji zwyczajnej poddane jest pod dyskusję. Dymisja zostaje przyjęta, jeśli uzyskała akceptację większości bezwzględnej deputowanych. Zarówno status, jak i uposażenie ministra, który podał się do dymisji lub wobec którego powzięta została decyzja o dymisji, określa stosowna po temu ustawa. W sytuacji opróżnienia urzędu ministra $\mathrm{w}$ wyniku wygaśnięcia sprawowanego przez niego mandatu, dymisji na wniosek własny bądź też zwolnienia z pominięciem jego bezpośredniego udziału, wszczęta zostaje procedura wyboru nowego ministra (art. 133). Zarówno szef rządu, jak i poszczególni ministrowie obdarzeni sa immunitetem per analogia jak deputowani do Zgromadzenia Narodowego Republiki Serbii, istota którego zawiera się par excellence w leksykalnym jego rozumieniu. Współdziałanie rządu i prezydenta opiera się więc na tym, że większość politycznych poczynań prezydent poprzedza konsultacjami z szefem rządu bądź całym rządem. Podobnie rzecz się ma w przypadku zasady niepołączalności 
funkcji, której zgodnie z art. 126 konstytucji, serbscy deputowani winni przestrzegać. Zatem władza wykonawcza w Republice Serbii niebanalnie wpisuje się w powszechnie przyjęte rozwiązania właściwe dla współczesnych demokratycznych systemów politycznych.

Urzędujący do 2012 r. gabinet M. Cvetkovicia składał się z 21 członków, w tym 4 wicepremierów i 1 ministra bez teki, obejmując 17 resortów. Rządowi podlegają ministerstwa oraz agencje i dyrekcje, wśród których na szczególną uwagę zasługuja: Biuro ds. Integracji Europejskiej, Agencja Inwestycji Zagranicznych i Promocji Eksportu, Agencja ds. Prywatyzacji, Agencja ds. Rozwoju MŚP, Agencja ds. Rozwoju Administracji Państwowej ${ }^{11}$, Agencja ds. Rozwoju Informatyki i Internetu, Agencja ds. Recyklingu, Agencja Rejestru Gospodarczego, Agencja Bezpieczeństwa i Informacji (odpowiednik Agencji Bezpieczeństwa Wewnętrznego w Polsce), Agencja ds. Walki z Korupcją Dyrekcja Dróg, Krajowy Urząd Zatrudnienia, Urząd Geodezyjny Republiki Serbii, Urząd Statystyczny Republiki Serbii, Urząd ds. Rozwoju, Urząd Ochrony Własności Intelektualnej, Pełnomocnik ds. Informacji o Znaczeniu Publicznym, Fundusz Rozwoju, Urząd Podatkowy, Urząd Celny, Urząd Zamówień Publicznych ${ }^{12}$.

\section{Sąd Konstytucyjny}

Zgodnie z art. 166 konstytucji Republiki Serbii: „Sąd Konstytucyjny jest samodzielnym i niezależnym organem, który chroni konstytucyjność i legalność oraz prawa i wolności człowieka i mniejszości” ${ }^{13}$. Sąd Konstytucyjny powołany jest do kontroli konstytucyjności aktów normatywnych. Na szczególną uwagę zasługuje fakt, że w wielu przypadkach orzeczenia Sądu Konstytucyjnego w Republice Serbii mają charakter precedensowych rozstrzygnięć, przesądzają spory interpretacyjne toczone nie tylko na gruncie doktryny, ale także i w praktyce. Przy czym pamiętać też należy, że w Republice Serbii funkcje, które powszechnie scedowane są na trybunały konstytucyjne pełni właśnie Sąd Konstytucyjny. Do głównych kompetencji zarezerwowanych dla tego organu należą takie czynności, jak np. orzekanie o zgodności ustaw i innych ogólnych aktów prawnych, ratyfikowanych umów międzynarodowych

${ }^{11}$ Administracja państwowa podlega rządowi, a swoje zadania realizuje za pośrednictwem ministerstw i innych urzędów (centralnych i terenowych). Zakres działania poszczególnych organów administracji państwowej oraz liczbę ministerstw określają ustawy. Wewnętrzną strukturę organizacyjną ministerstw i pozostałych urzędów określa rząd, por. http://www.msz.gov.pl (dostęp 1 VIII 2011).

12 Tamie.

${ }_{13}$ S. Biševac, Manjine u Srbiji, Beograd 2000, passim. 
z konstytucja. Także orzekanie o zgodności ogólnych aktów z ustawą zgodności statutów i ogólnych aktów normatywnych pokrain i jednostek samorządu lokalnego z konstytucją i ustawa, zgodność ogólnych aktów właściwym organizacjom, którym powierzone zostały obowiązki publiczne, np. partie polityczne, związki zawodowe, stowarzyszenia obywateli (art. 167).

Nadto do Sąu Konstytucyjnego w Republice Serbii należą typowe dla każdego Sądu Najwyższego kompetencje, takie jak np. rozstrzyganie sporów kompetencyjnych pomiędzy sądami i innymi organami państwowymi, sporów kompetencyjnych pomiędzy organami republiki i autonomicznymi pokrainami lub organami jednostek samorządu lokalnego, sporu kompetencyjnego pomiędzy organami autonomicznych pokrain i organami jednostek samorządu lokalnego, jak też pomiędzy różnorodnymi organami autonomicznych pokrain lub różnymi jednostkami samorządu lokalnego. Wachlarz uprawnień właściwy serbskiemu Sądowi Konstytucyjnemu został znacznie poszerzony o zadania w zakresie rozpatrywania protestów wyborczych, jak również orzekania w kwestii zakazu funkcjonowania partii politycznych i związków zawodowych (art. 167).

Należy zwrócić uwagę, że Sąd Konstytucyjny w Republice Serbii precyzuje interpretację konstytucji, co następnie powinno być nie tylko bezwzględnie brane pod uwagę, ale też i respektowane przez organy stanowiące i stosujące prawo w państwie. Sąd Konstytucyjny Serbii określa nie tylko to, które z norm prawnych są zgodne z konstytucja, lecz także kataloguje te ustawy, których treść nie jest zgodna $\mathrm{z}$ ustawą zasadniczą. Z tego powodu niekiedy określa się serbski Sąd Konstytucyjny, podobnie zreszta jak Trybunał Konstytucyjny w Polsce, jako „negatywnego ustawodawcę”. Sąd Konstytucyjny ma w Serbii wpływ na sposób rozumienia ogólnych aktów prawnych (per analogia akty podkonstytucyjne w Polsce). Także do Sąu Konstytucyjnego należy rozpatrywanie skargi konstytucyjnej, która zgodnie ze stanowieniem art. 170 może być zgłoszona przeciwko jakiemuś aktowi prawnemu lub pracy organów państwowych, lub też jakiejś organizacji, której powierzone zostały funkcje publiczne, a które ograniczaja prawa i wolności człowieka i mniejszości gwarantowane w konstytucji Serbii.

Pamiętać należy, że w systemie politycznym Republiki Serbii skarga konstytucyjna jest relatywnie nową instytucją. Jej zasadność wywodzi się z uznania nadrzędności konstytucji nad innymi aktami prawnymi i stworzenia szczególnego instrumentu dla ochrony praw konstytucyjnych ${ }^{14}$. Należy zauwa-

${ }^{14}$ Instytucja skargi konstytucyjnej szczególnie wyróżnia prawo niemieckiego obszaru językowego, a jej pierwowzoru należy szukać w Bawarii, gdzie na mocy rozporządzenia królewskiego z 1814 r. dopuszczono skarge jednostki w przypadku naruszenia gwarantowanych jej konstytucyjnych praw. W prawie austriackim takim pierwowzorem skargi była skarga do Sądu Rzeszy wprowadzona w $1867 \mathrm{r}$. w podobnych sprawach. Nie należy jednak zapominać, że idea ochrony praw jednostki poprzez indywidualne instrumenty prawne ma 
żyć, że skarga konstytucyjna może występować w dwóch zasadniczych formach: podmiotowej i przedmiotowej. Przyjęto, że istota tej pierwszej polega na ochronie praw konstytucyjnych konkretnej osoby poprzez danie jej możliwości uruchomienia procedury kontroli konstytucyjności aktów władzy publicznej. Natomiast funkcja przedmiotowa skargi konstytucyjnej zawiera się w procesie kontroli konstytucyjności wskazanych aktów. Przy czym chodzi tu nie tylko o ochronę praw pojedynczej osoby, lecz także o usunięcie z systemu prawa aktów pozbawionych konstytucyjności. Warto zaznaczyć, że do znajomości normatywnej treści ustawy zasadniczej konieczna jest znajomość orzecznictwa Sąu Konstytucyjnego. Orzecznictwo to jest szczególnie istotne dla organów prawotwórczych, gdyż formułuje szereg warunków konstytucyjności aktów normatywnych.

W skład Sądu Konstytucyjnego Republiki Serbii wchodzi 15 sędziów, którzy są wybierani na okres 9 lat. Przy wyborze sędziów określony został następujący parytet: 5 sędziów zostaje wybranych spośród 10 zaproponowanych przez Zgromadzenie Narodowe, których wybiera prezydent, 5 sędziów pochodzi z gremium ogólnego posiedzenia Najwyższego Sądu Apelacyjnego Serbii. Najwyższy Sąd Apelacyjny mianuje 5 sędziów spośród 10 kandydatów, których zaproponowały, odbywając wspólne posiedzenie, Najwyższa Rada Sądownicza i Państwowa Rada Prokuratorów. Należy zauważyć, że przy tym wyborze szczególnie zadbano o przestrzeganie wszelkiej staranności polegającej na tym, że na każdej zaproponowanej liście kandydatów, jeden z wybranych obowiązkowo musi pochodzić z terytorium autonomicznej pokrainy (do 2008 r. wymóg ten dotyczył Kosowa, ta zasada wciąż aktualna jest co do Wojwodiny). Sędziowie Sądu Apelacyjnego ze swego grona wybieraja prezesa na okres trzech lat, co czynią w głosowaniu tajnym. Sędziów Sądu Apelacyjnego wybiera się spośród wybitnych i znanych prawników, którzy w chwili wyboru mają ukończone co najmniej 40 lat, i majacych przynajmniej 15 lat doświadczenia w wykonywaniu zawodu prawnika.

Przyjęto zasadę, że ta sama osoba nie może pełnić funkcji sędziego Sądu Konstytucyjnego dłużej niż dwie kolejno po sobie następujące kadencje, czyli maksymalnie 18 lat (art. 172). Sędziowie Sądu Konstytucyjnego zaprzestają pełnienia swojej funkcji bądź na swą własną prośbę (np. przejście na emeryturę), bądź mogą zostać zwolnieni, jeśli naruszą zasadę niepołączalności funkcji lub jeśli dopuszczą się przestępstwa, które uczyni z nich niegodnych sprawowania funkcji sędziego Sądu Konstytucyjnego. O zwolnieniu z funkcji sędziego decyduje

o wiele bardziej odległą historię, gdyż jej źródeł poszukiwać należy w wydanej przez Króla Jana bez Ziemi Wielkiej Karcie Swobód pochodzącej z 1215 r., uważanej dość powszechnie za początek procesu kodyfikacji praw człowieka. Zob. Prawo konstytucyjne Rzeczypospolitej Polskiej, red. P. Sarnecki, Warszawa 2008, s. 164; P. Motyka, Prawa człowieka, Lublin 2004, s. 33; R. Kuźniar, Prawa człowieka. Prawo, instytucje, stosunki międzynarodowe, Warszawa 2008, s. 21; Ustavnost i vladavina prava, ur. K. Čavoški, Beograd 2000, passim. 
Zgromadzenie Narodowe, natomiast inicjatywa w sprawie wszczęcia postępowania w tym przypadku należy do Sądu Konstytucyjnego (art. 174). Sędziowie Sądu Konstytucyjnego objęci są zasadą niepołączalności funkcji z wyjątkiem łączenia funkcji sędziego Sądu Konstytucyjnego z funkcja profesora wykładającego na wydziale prawa w Republice Serbii, co dzieje się zgodnie z ustawą (art. 173). Każda decyzja (orzeczenie) podejmowana przez Sąd Konstytucyjny zapada większością głosów wszystkich sędziów Sądu Konstytucyjnego (art. 175). Należy zauważyć, że Sąd nie działa ex officio, a tylko na wniosek konstytucyjnie uprawnionych do tego podmiotów. Takie prawo przysługuje Zgromadzeniu Narodowemu, prezydentowi, rządowi, a w kwestii kontroli zgodności norm również Obrońcy Obywatela (Ombudsman). Jak już wspomniano, Sąd Konstytucyjny w Republice Serbii ustala wykładnię konstytucji, która następnie powinna być respektowana przez organy stanowiące i stosujące prawo. Warto zaznaczyć, że dla znajomości normatywnej treści ustawy zasadniczej konieczna jest znajomość orzecznictwa Sądu Konstytucyjnego. Orzecznictwo to jest szczególnie istotne dla organów prawotwórczych, gdyż formułuje szereg warunków konstytucyjności aktów normatywnych.

\section{Obrońca Obywatela (Ombudsman)}

Konstytucja Republiki Serbii z 2006 r. w kwestii stanowienia na temat Obrońcy Obywatela sięga do koncepcji instytucji czuwającej nad prawidłowością działania administracji, którym historycznie rzecz biorąc stał się mający już chlubną tradycję szwedzki urząd Ombudsmana ${ }^{15}$. Ustawodawca serbski na mocy art. 138 ustanowił instytucję Ombudsmana, któremu powierzono ochronę praw i wolności człowieka i obywatela oraz badanie naruszeń praw jednostki w stosunkach z instytucjami państwowymi. Obrońca Obywatela, gdyż taka jest nazwa własna w dosłownym tłumaczeniu Rzecznika Praw Obywatelskich w Serbii, jest niezależnym organem państwowym. Do jego kompetencji, oprócz wyżej wskazanych, należy kontrolowanie pracy organów administracji państwowej, organów właściwych dla prawnej ochrony własności prawa i interesu Republiki Serbii oraz innych podmiotów i organizacji, przedsiębiorstw i instytucji, którym sa powierzone kompetencje publiczne. Do kompetencji serbskiego Rzecznika Praw Obywatelskich nie należy kontrolowanie pracy Zgromadzenia Narodo-

15 W 1709 r. utworzono w Królestwie Szwecji instytucję Ombudsmana, który nieco później stał się pierwowzorem dla powołania do życia tej instytucji w innych państwach, czego dowodem jest szersze oddziaływanie skandynawskich rozwiązań w tej materii, np. upowszechnienie stosowania nazwy tego urzędu dla określenia analogicznych instytucji. 
wego, prezydenta, rządu, Sądu Konstytucyjnego, sądów i prokuratury. Obrońca Obywatela za wykonywanie swej konstytucyjnej funkcji ponosi odpowiedzialność przed Zgromadzeniem Narodowym Republiki Serbii, które nie tylko dokonuje jego wyboru, lecz także wyposaża ten organ w immunitet identyczny z tym, z jakiego korzystają deputowani.

W związku z powyższym należy zauważyć, że serbski Rzecznik Praw Obywatelskich zawiera w sobie klasyczne cechy charakterystyczne dla tego organu. Przede wszystkim jest to samodzielny organ państwowy posiadający status konstytucyjny, wyraźnie oddzielony od organów administracji i sądownictwa. Należy zaznaczyć jednak, że w relacjach serbskiego Ombudsmana ze Zgromadzeniem Narodowym Republiki Serbii występuje relatywnie duży stopień niezależności, jednocześnie jednakże przy wielu powiązaniach zarówno organizacyjnych, jak i funkcjonalnych tej instytucji z ciałem przedstawicielskim. Urzędowi Rzecznika Praw Obywatelskich w Serbii przypisana jest realizacja dwóch uzupełniających się funkcji: pierwszej polegajacej na wysłuchiwaniu skarg obywateli na nieprawidłowe działania organów państwowych (szczególnie zaś administracji), jak również drugiej polegającej na podejmowaniu stosownych działań w tym zakresie oraz informowaniu Zgromadzenia Narodowego o stanie praworządności w państwie, przede wszystkim w aspekcie przestrzegania praw i wolności obywatelskich. W omawianym przypadku współczesnego serbskiego ustroju politycznego za jeden z jak najbardziej pozytywnych atrybutów uznaje się relatywnie łatwy dostęp obywateli do tego organu, który charakteryzuje się daleko idącym odformalizowaniem procedury postępowania.

Ważna właściwością omawianego tu organu jest nadto swoboda podejmowania decyzji o wszczęciu czynności w konkretnej sprawie, przy równoczesnym pozbawieniu go kompetencji o charakterze władczym i rozstrzygajacym. Rzecznik Praw Obywatelskich w Serbii, zgodnie z wyżej cytowanym artykułem konstytucji, jest organem „niezależnym”, co przede wszystkim wiąże się z aspektem organizacyjnym oraz brakiem podległości, z wyjątkiem ograniczonej do przypadków, które przewiduje ustawa. Ma się tu na względzie szczególnie odpowiedzialność przed Zgromadzeniem Narodowym. Nie ulega wątpliwości, że gwarancją zasady niezależności jest przywilej immunitetu formalnego oraz nietykalności Obrońcy Obywatela. W obowiązującym we współczesnej Republice Serbii stanie prawnym właściwość Obrońcy Obywatela ma w pewnym sensie charakter generalny, co oznacza, że wszelkie prawa i wolności dają się wywieźć z obowiązujących norm prawnych. W aspekcie podmiotowym art. 138 serbskiej konstytucji zawiera szerokie określenie właściwości tego organu, obejmujące prawa i wolności przysługujące w Serbii nie tylko obywatelom, ale także mniejszościom narodowym, które literalnie zostały wymienione w cytowanym artykule ustawy zasadniczej. 
Rozważając zagadnienie zakresu działań kontrolnych Obrońcy Obywatela należy zwrócić uwagę, że w sprawach związanych z ochroną praw i wolności obywateli bada on, czy wskutek działania lub zaniechania działań organów, organizacji i instytucji, obowiązanych do przestrzegania i realizacji tych praw i wolności przypadkiem nie nastapiło naruszenie prawa bądź też nie zostały naruszone zasady współżycia i sprawiedliwości społecznej (art. 1). W związku z powyższym mamy tu do czynienia z dwoma istotnymi aspektami funkcjonalnymi: pierwszy - polegający na tym, że przedmiotem zainteresowań Obrońcy Obywatela w Republice Serbii są wszelkie zachowania (nie wyłączając także i tych, które polegają na zaniechaniu podejmowania nakazanych prawem czynności) organów państwowych oraz także tych podmiotów, które co prawda organizacyjnie nie mieszczą się w zakresie ściśle rozumianego aparatu państwa, lecz uczestniczą w wykonywaniu władzy publicznej (np. stowarzyszenia, samorządy lokalne wykonujące tzw. zadania zlecone).

Obrońca Obywatela w Republice Serbii jest nadto upoważniony do reagowania w sytuacjach, gdy jakiś organ działa contra legem ze względu na przestrzeganie i realizację praw lub wolności jednostki i mniejszości narodowych, jak też interpretacji tzw. klauzul generalnych zawartych w przepisach prawa. Konstytucja Republiki Serbii nie przewiduje oddzielnego rozdziału na temat instytucji Obrońcy Obywatela, a jedynie poświęca temu organowi jeden artykuł, fakt ten nie oznacza jednak, że organ ten - choć nie ma tu żadnych tradycji - jest deprecjonowany we współczesnym systemie politycznym Republiki Serbii.

$$
\text { * * * }
$$

W powyższych rozwiązaniach wskazano na wybrane organy tworzące aparat państwowy państwa znajdującego się wciąż jeszcze na jednym z wczesnych etapów transformacji ustrojowej. Już ta krótka analiza instytucjonalna pozwala na wyprowadzenie wniosku, że kierunek reform serbskiego ustroju politycznego jak najbardziej wpisuje się w nurt przemian demokratycznych. Na szczególną uwagę zasługuje uwzględnienie obok ciała ustawodawczego, wykonawczego i sądowniczego także Obrońcy Obywatela - nowego w swej istocie urzędu stojącego na straży praworządności, zatem strzegącego prawa oraz dbałości o to, by działania organów i urzędów państwowych odbywały się zgodnie z prawem. $\mathrm{W}$ ten sposób zabezpieczony instytucjonalnie obywatel przynajmniej teoretycznie może czuć się bezpiecznie w państwie, które jeszcze do niedawna trudno było uznawać za praworządne. Stąd też świadomość serbskiego obywatela o możliwości pomocy prawnej w razie zaistniałej konieczności w konstytucyjnie powołanej instytucji, wydaje się nie być pozbawiona znaczenia. Serbski Ombudsman, także i z racji niedawno toczonego konfliktu narodowościowego na obszarze nas inte- 
resującym, wydaje się instytucją ze wszech miar pożądaną nie tylko w zapisie konstytucji, lecz także w praktycznym funkcjonowaniu.

Przeprowadzona analiza rozpatrywanych w toku wywodu elementów konfigurujących naczelne organy władzy państwowej w Republice Serbii, a omówionych w kontekście ich legitymizacji rozumianej jako zapis w treści materii ustaw, upoważnia do konkluzji, że serbski konstytucjonalista zadbał o to, by zapisy tkwiące w konstytucji z $2006 \mathrm{r}$. w odniesieniu do kwestii wziętych tu pod uwagę organów zarówno jeśli chodzi o sposób kreowania, pełnione funkcje ustrojowe, jak i ich dymisjonowanie, jednoznacznie utwierdzały w przekonaniu o wyborze demokratycznego kierunku rozwoju państwa, znajdującego się na etapie jakże złożonego, bo wielopłaszczyznowego, a w przypadku interesującej nas Republiki Serbii, szczególnie problematycznego procesu transformacji ustrojowej. 